\title{
AN OLD UIGUR VERSION OF THE KASIBHĀRADVĀJA SUTTA EXTENDED BY A POEM
}

\author{
ZHANG Tieshan $^{1}$ and Peter ZIEME ${ }^{2}$ \\ ${ }^{1}$ Academy for Research on Chinese Ethnic Minority Languages, Minzu University of China, \\ 27 Zhongguancun South Avenue Haidian District, Beijing, 100081, P. R. China \\ e-mail: zhangtieshan@sina.com \\ ${ }^{2} 16816$ Neuruppin, Schinkelstr. 12, Germany \\ e-mail: ziemepet@gmail.com
}

In this paper, we introduce some new fragments preserved at the Dunhuang Academy. These are five detached pieces of a Chinese scroll of the Prajñāpāramitāsūtra (Da banruo boluomiduo jing 大般若 波羅蜜多經). The first text on the verso side is a conversation between a brahman and the Buddha. It is similar to the Kasibhāradvāja sutta which is a talk between a brahman working as a ploughman and the Buddha who comes to him to beg for food. One gets the impression that the Old Uigur text is essentially based on the Pāli text. After a long gap, the second text presents quatrains following the metrical structure of Buddhist verses, as they were widespread among the Old Uigurs. We edit the texts with transliteration and transcription, as well as offer an English translation accompanied by comments.

Key words: Dunhuang Academy, Uigur Buddhism, Kasibhāradvāja sutta, Buddhist quatrains.

\section{Introductory Remarks}

In this paper, we introduce some new fragments preserved at the Dunhuang Academy. ${ }^{1}$ These are five detached pieces of a Chinese scroll of the Prajñāpāramitāsutra ( Da banruo boluomiduo jing 大般若波羅蜜多經), and the verso side of the scroll was re-used for writing some Old Uigur texts. Looking from the recto side, the fragments can be directly joined in two portions: one consists of two joined pieces (D0585 2 D0584 $4^{3}=$

${ }^{1}$ We express our gratitude to Marcel Erdal who kindly read the manuscript and offered us important suggestions and improvements (for details cf. notes). We also thank the anonymous reviewer for the remarks and proposals (cf. notes).

${ }^{2}$ Size: $17 \times 26.8 \mathrm{~cm}$.

${ }^{3}$ Size: $18.3 \times 26.8 \mathrm{~cm}$. 
T.VI.220.1044a07-27), the other of three (D0583 ${ }^{4}+\mathrm{D} 0581^{5}+\mathrm{D} 0582^{6}=$ T.VI.220. 1044b21-c19) with a long lacuna of 51 Chinese columns. It is supposed that these fragments belong to the findings from the Mogao caves near Dunhuang, but this is not certain.

\section{The recto side}

The Chinese text on the recto side of D0585R+D0584R (lacuna) D0583R+D0581R+ D $0582 \mathrm{R}^{7}$ reads as follows.

01 T06n0220_1044a07爾時, 具壽善現白佛言：「世尊！若如是法是菩 ${ }^{08}$ 薩

02 法, 復何等法是佛法耶? 」佛告善現：「汝所問

03 年言：『若如是法是菩薩法, 復何等法是佛法? 』者, ${ }^{10}$ 善

04 現! 即菩薩法亦是佛法。謂諸菩薩摩訶薩

$05{ }^{11}$ 於一切法覺一切相, 由此當得一切相智, 永 ${ }^{12}{ }^{4}$

06 一切習氣相續; 若諸如來、應、正等覺, 於一

$07{ }^{13}$ 切法以一刹那相應妙慧現等覺已, 證得無

$08{ }^{14}$ 上正等菩提。善現! 如是菩薩與佛有異如二

$09{ }^{15}$ 聖者, 雖俱是聖而有行向、住果差別。如是, 善

1016 現! 若無間道中行於一切法, 未離闇障, 未到

1117 彼岸, 未得自在, 未得果時, 名為菩薩摩訶薩。

1218 若解脫道中行於一切法, 已離闇障, 已到彼

13 19岸, 已得自在, 已得果時, 名為如來、應、正等覺。

1420 善現! 是為菩薩與佛有異, 雖位有異而法

15 無 ${ }^{21}$ 別。」時, 具壽善現白佛言：「世尊！若一切法自相

16 22皆空, 自相空中云何得有種種差別, 謂此是

1723 地獄, 此是傍生, 此是鬼界, 此是天, 此是人,

$18{ }^{24}$ 此是種姓地, 此是第八地, 此是預流, 此是 ${ }^{25}$ 一來, 此

19 是不還, 此是阿羅漢, 此是獨覺, 此是 ${ }^{26}$ 菩薩

20 [摩訶薩, 此是如來、] 應、正等覺? 世尊! 如此 ${ }^{\text {T06n0220_p1044a27 所說 }}$ (lacuna)

21 T06n0220_p1045b21 [性即四聖諦。] 所有眞如法 [界法 ${ }^{22}$ 性、不虛妄性、]

22 不變異性、法定、法住、平等性、離[生 ${ }^{23}$ 性、實際、虛]

23 空界、不思議界, 如來出世、若不出 ${ }^{24}$ 世性相常

24 住, 無失壞、無變易, 如是名為四聖 25 諦平等性。

25 諸菩薩摩訶薩修行般若波羅蜜 ${ }^{26}$ 多時, 為欲

\footnotetext{
${ }^{4}$ Size: $18.8 \times 23.2 \mathrm{~cm}$.

${ }^{5}$ Size: $11.5 \times 19.6 \mathrm{~cm}$.

${ }^{6}$ Size: $17 \times 26.4 \mathrm{~cm}$.

${ }^{7}$ The first number represents the line number of the combined fragments, while the index number refers to the arrangement in the Dazheng Xinxiu Dazangjing 大正新脩大藏經 // Taishō
} Daizōkyō (CBETA // SAT). 
26 隨覺此四聖諦平等性故修行般 27 若波羅蜜

27 多, 若能隨覺此四聖諦平等性時, 28 名真隨覺

28 一切聖諦。」

29 時, 具壽善現白佛言 : $\left\ulcorner 世^{29}\right.$ 尊 ! 云何菩薩摩訶薩

30 為欲隨覺此四聖諦平 ${ }^{\mathrm{T} 06 \mathrm{n} 0220}$ p $1045 \mathrm{c} 01$ 等性故, 修行般若波

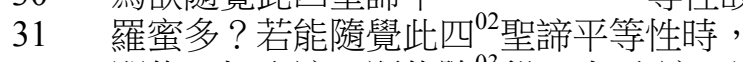

32 即能一切聖諦, 既能隨 33 覺 [一切聖諦, 即能如]

33 實修菩薩行, 既能如實 ${ }^{04}$ 修菩薩行, [不墮聲]

34 聞及獨覺地, 趣入菩薩正 ${ }^{05}$ 性 [離生? 佛告善]

35 現: 「諸菩薩摩訶薩修行般[若06波羅蜜多時, 無有]

36 少法不如實見, 於一切法 [ ${ }^{07}$ 如實見時, 於一切法 $]$

37 都無所得, 於一切法無 ${ }^{08}$ 所得時, 則[如實見一]

38 切法空, 謂如實見四諦 ${ }^{09}$ 所攝及所[不攝諸法]

39 皆空。如是見時能入菩 ${ }^{10}$ 薩正性離生, 由能入

40 菩薩正性離生故, 即住 ${ }^{11}$ 菩薩種姓地中。既住

41 菩薩種姓地中, 則能 ${ }^{12}$ 決定不從頂隋, 若從頂

42 墮應墮聲聞或獨覺 ${ }^{13}$ 地。「善現! 是菩薩摩訶薩

43 安住菩薩種姓地 ${ }^{14}$ 中, 能起四靜慮及起四無

44 量、四無色定。是菩15薩摩訶薩安住如是奢摩

45 他地, 能決擇一切法 ${ }^{16}$ 及隨覺四聖諦。是菩薩

46 摩訶薩雖遍知苦而 ${ }^{17}$ 能不起緣執苦心, 雖永

47 斷集而能不起緣執 ${ }^{18}$ 集心, 雖證於滅而能不

48 起緣執滅心, 雖修於 ${ }^{19}$ 道而能不起緣執道心,

\section{The verso side}

The verso side of this scroll bears Old Uigur texts written along the full height of the paper. The fragments can be joined following the Chinese text of the recto side. Because of the long interval, it remains unclear whether the two sections belong to one and the same text. The first section is written in prose, the second one in metrical quatrains.

The Uigur script of a cursive type that was often used in Yuan times can clearly be read, but sometimes the difference between the letters Alif and Yà are minimal. As the final stroke of the letters $\mathrm{K}$ and $\mathrm{P}$ turn back to the estimated line, one gets the impression that there are more hooks than necessary. There are numerous examples of voice confusion which is also typical of the Mongol period (13th/14th centuries). In the second section, the verses are separated by two dots or strokes (:), the stanzas by a group of four dots (::).

Besides the fragments of the Dunhuang Academy (ms. A), there are four other manuscripts in the Turfan Collection of the Berlin Brandenburg Academy of Sciences and Humanities (mss. B, C, D, E). 


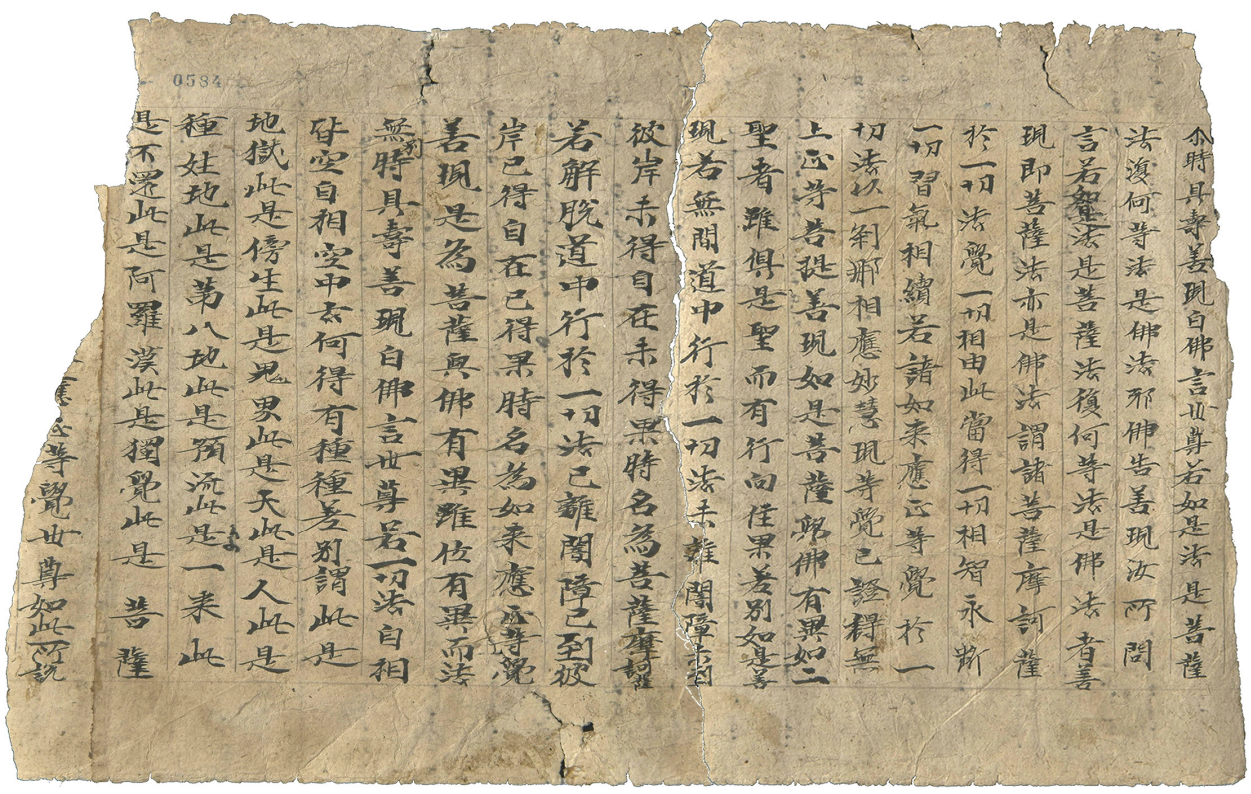

Figure 1. D0585R+D0584R

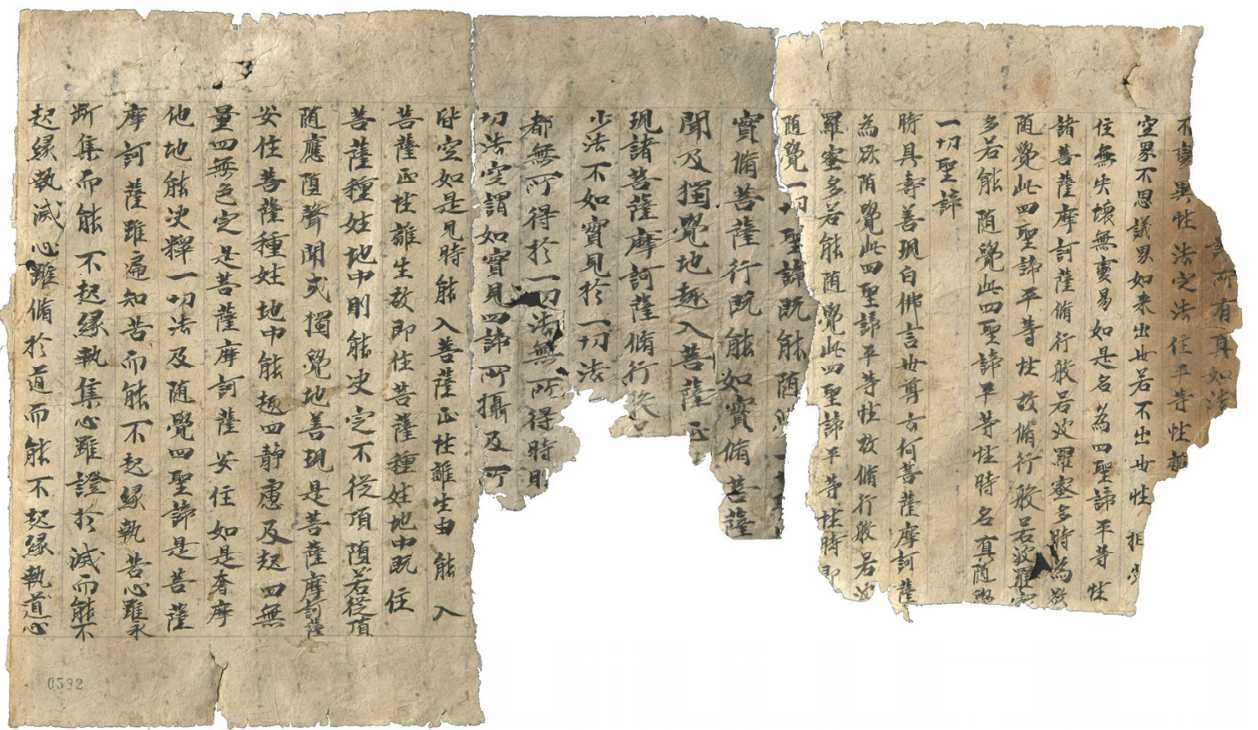

Figure 2. D0583R+D0581R+D0582R 


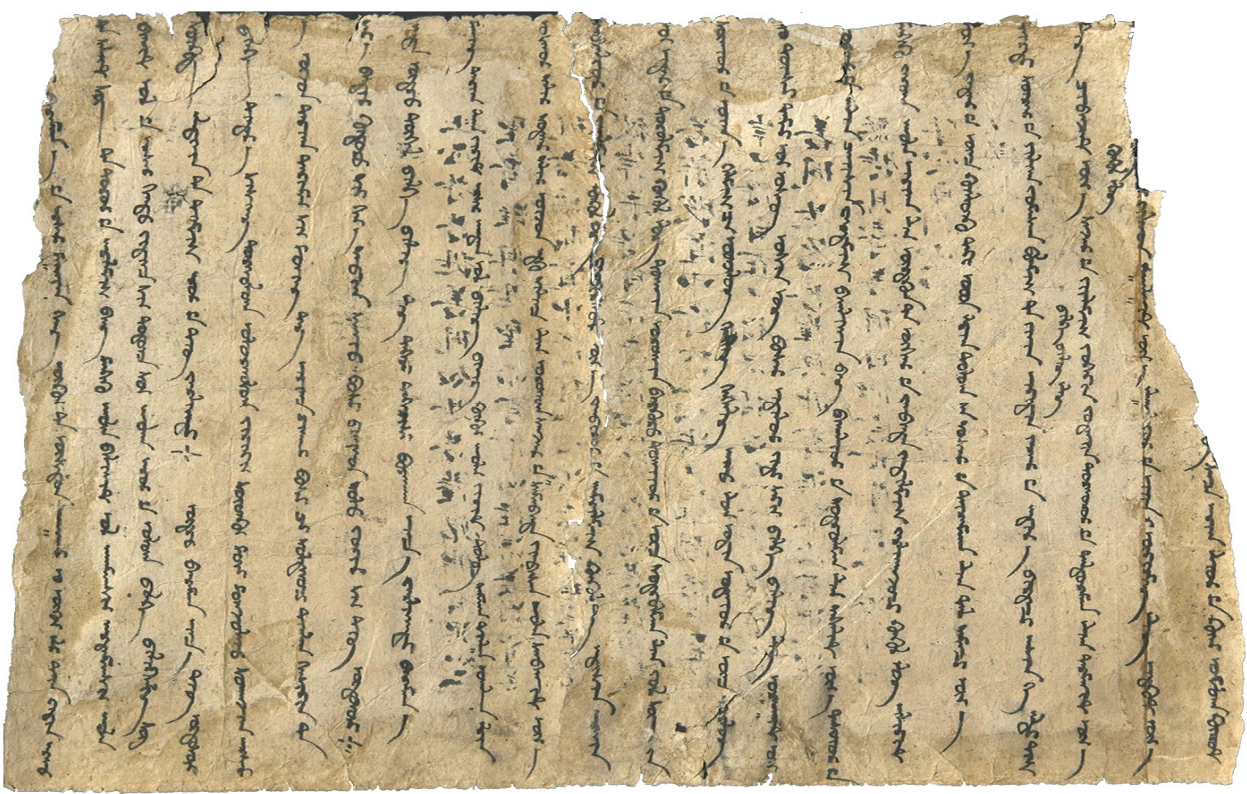

Figure 3. D0585V+D0584V

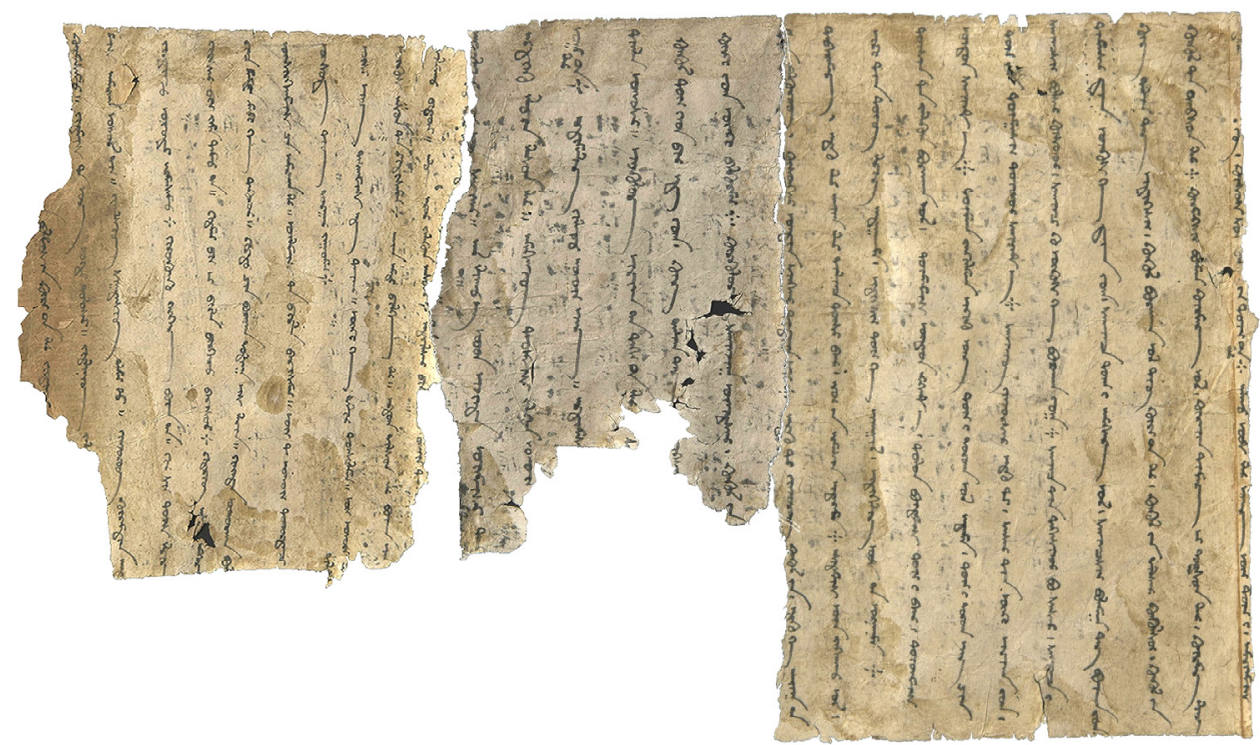

Figure 4. D0583V+D0581V+D0582V 
Transliteration of the Old Uigur texts ${ }^{8}$

\section{Manuscript A}

First section D0584V + D0585V (directly joined)

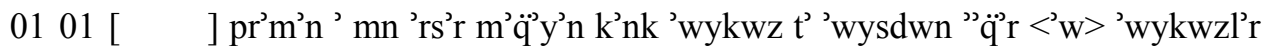
tyn kydyn "rqw

$0202 \mathrm{t}^{\prime} \mathrm{s}^{\prime}$ lqym swv t' twrwr mn "rl'mys ${ }^{\prime} \mathrm{p}^{\prime} \mathrm{k}$ m’nkkw "tlq p'lyqym 'wl "qm'qsyz "rd'm'qsyz "tlq

0303 p'rqym ${ }^{10}$ wl mn 'rs'r k’ndw yydynč syz twdwnč swz "tlq 'rwr mn 'wlwq pylk' pylyklyk $<$ swd $>$

0404 swykwd 'ldynyn t' tynmys 'rwr mn typ y'rlyq'dy :: 'wydrw p'r'm'n 'ynč ' typ 'wydwnty

0505 pylk' tynd'r ' sysynk twrqwlwq 'wlwrqwlwq yyrynkyz swvwnkwz mwny mwnčwl'yw swq'nčyq 'rs'r

0606 [ ] 'wyčwn t’ryq t'rym'z syz mwnynk t’k 'yrynč čyq'y pwsy čy qwldqwčy tynlq k'sykyn $\mathrm{t}^{3}$

0707 "y 'p'dyr kwydwrw qyy k’z ' q'pyq s'n'yw .. pwsy pynv't qwlw ywryr syz typ 'wydwnty $\because$

0808 'nd' 'wydrw twyk'l pylk' pylyk lyk tnkry tnkrysy pwrq'n 'ynč ' y'rlyq'dy $p^{\prime} r^{\prime} m^{\prime} n{ }^{\prime}$

0909 m’nynk t’ryq l'ä yyrym 'rs'r "nd'q 'wl pylyk pyryk kwykwz "tlq yyrym twlp q'm’q tynlä 'wql’n l’ryq

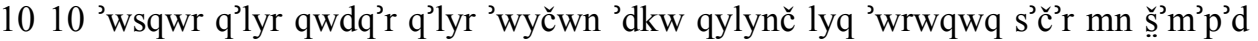
vyp's'n "tlq s'np'rym 'wyz'

1111 s'p'nl'ywr mn y’v'lmys kwnkwl lwk y’pyrqwm 'wyz ' y'pyrwr mn 'mrylmys kwnk[ ]l[ ] "dysyn "ryqyn

1212 'wz 'yd'r mn twrwlmys kwnkwl lwk twqyn 'wrwqyn p'rkwrw twqyywr mn 'wyč qwdrwlm'q lyq ywl swv yn

1313 swv'ywr mn 'wyn 'k'lmyš č' 'wwčlwk < k'kyk> k'klyk "qw lwq 'wdyn 'wd'ywr mn .. 'wyč twyrlwk

1414 [ ]qw twysy t'my 'wz 'ws'p 'wsyn 'wk pws'r 'ydylwr yydy sykyz pylk' pylyk lyk 'wrö' q̈ym 'wyz'

1515 'wr'r mn '’lyn č̀vysyn y'rdmys p'qlyqyn p’k p'ql'ywr mn qwdrwlm'q lyq q'nklym 'wyz' t'swywr mn

1616 m'nkkw y'rwq "tlq nyrv'n lyq 'wyrdkwn t' 'wyk'r mn y'p'd' y'dylmys y'rlyq'nčwčy kwnkwl lwk ’ylykym

${ }^{8}$ The lines are numbered in a double way: in the first column, the numbers stand for the continuous numbering through the whole manuscript, while in the second column, numbering restarts in the two sections.

${ }^{9}$ Mistake for " mrylmys?

${ }^{10}$ Mistake for p'lyqym? 
1717 'wyz 'y'd'r mn 'wyč kwylwnkw t'ky 'wwt l'ryq twlwq q' qwš'r mn t'vr'nm'q lyq t'l q'mčy 'wyz'

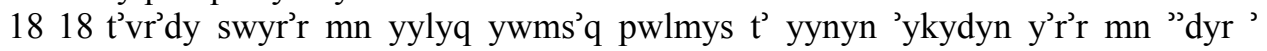
pyrd'čy "syn k' 'ldy tys

1919 lyk čpč̀m 'wyz' s'č’r mn yylmyš (pylk' pylyk lyk) ywk'kyn ywd'nyn twrqwrwr mn t'ldwrm'q lyq t'rm'qym 'wyz'

2020 [ ] (kwnkwl lwk) [ ]z y'lqwq l’äl'äym 'wyz' l'äl'ywr mn ’yyyn < y> 'wykyrm'k lyk 'dkwm 'wyz'

$2121[$ ] ] s'č "'ryq l'ywr mn kwyny nwmlwq kwyrwm [

Second section D0583V + D0581V + D0582V (directly joined)

2201 [ ]n pwlmysyn kwyrzwn l'r yyrdynčw[

$2302 \mathrm{kwyrm}$ 'smw .. yydmys t' 'wk 'wydy qwlwsy .. yydlyniyp y'l[

2403 mys 'mr'q 'wqwl qyz .. yyql'syp syäd'syp qlm’z mw .. yynčwrwp kwyrm'dyn 'rd[

2504 yyrdynčw 'wvwdy 'rm'smw :: kyrtkwnkw k'rk'k pwy’n q' .. kyr syz twys l'ryk [ ]

2605 kyrs'r pyz y’m' t’mw q' .. kydm'z pyz ny pyrl' pyrk'rw p'ryswr :: kyd'ryp "läw 'mk'k [

2706 kyč m'dyn m’nky k' t’kwrwr .. kyrdw čyn pwrq'n 'wdl'ä 'yš l’ryn .. kynynd' wtqwr'q pwl[]

2807 'wysyrk'nmys č 'mr'q l’r .. 'wylmys t' pyrl' p'rysm'z .. 'wyz-<t>-'t’wyz twqwrd’čy [ ]

2908 'wyswd typ qwrö'r y'äwm'z:: (lacuna) tyl[ $]^{11}$

3009 'wysy nynk q'zq'nmys 'd t'v'r .. 'wynky k' q'lyr twswlm'z .. 'wyz 't’wyz [ ]

3110 'wykws "ṣ̌wn t' kydyšm'z :: "nyn 'mdy pylk' l’r .. 'rdwq qylswn l'r pwy'n nyq

3211 qylm'qw pyd'ty .. 'lp 'rwr y'lnkwq "swny :: "dryls'r pyz [ ] t'wyz tyn [ ]

3312 "nčwl'yw 'rwr [ ]w swd'qy .. "l lynqw "wwt 'yčynd" 'wynmysy t’nk[ ]

3413 'rdynkw 'lpyn 'lswn l'r .. 'mk'nyp t'pmys y'lnkwq 't'wyz [

3514 'wäzwn(l’r) :: 'rdymlyk yylynw 'twyz nynk .. 'rdyms[yz

3615 tynlq 'wqwšsy .. 'ynčkwlwk nyrv'n q' t'kzwn l’r [ ] s' [

3716 kwnkwl twyz ynt pyr'd ywq . kwyk q'lyq t’k [ ]yks[

3817 kwyrky ywq 'wynky plkwrm’z :: kwyrkwlwk s'qynčyä ’wyryds'r . kwnkwl yn [ ]

$3918 \mathrm{p}[\quad]$ ' plkwrwp . kwyswnk'y 'wndyn synk'r tvr'q syz . 'dkw ty yynčwrwp kwnkwl yn. 'dkw k' "yyq̈ q'

4019 t’pr'm'k ${ }^{12}$.'dkw ly "yyq ly qylynč twyšy p'r . 'rwr yn 'rm'syn 'yd'rm' :: 'ysydmys 'wyn ynkqw 'wl .

\footnotetext{
${ }^{11}$ As this word is unclear, we omitted it in our transcription.

${ }^{12}$ The letter - $p$ - is written as in some late manuscripts with a hook leading to the line.
} 
4120 'yky tyn twyp l'ryk 'dq̣'nm' . 'ydyksyz twyz k' 'yn'näyl . 'ydyklyk nwwm t' 'wrìn'n' ::

4221 twysyn t' y'lnkwq pwrq'n 'wl . twym'mys 'wydwn 'mk'nm '. twlwn pwydmyš twyz y p'r . twywnmys

4322 'wydwn s'vynm ':: twym'q y'nkylm'q 'ykykw nwnk twyzy qwrwq 'wl 'd'm'. twyz y qwrwq nynk čyn

4423 twyz yn twym' $\ddot{s} s y z$ twywrwr s’vynm ' :: s' $q y n y p$ yynčwrs'r 'dkw ty . s'ns'r tyn 'wynky 'yr'q ywq .

4524 s'qynčsyz pwls'r kwyswnwr . s'qynč <kw> 'wykws k' pwrq'n ywq :: s'qynč tyn t'ksynwr pw s'ns'r . s'qynč y

$4625<$ tym's'r dyn> 'wykws k' dyn ywq. s'qynč twyz y 'mk'k 'wl . sqynčsyz pwlm'ä $t^{2} k$ pwy'n ywq .

4726 kwyk q'lyq t’k 'ydyksyz . kwnkwl pwrq'n 'wl typ kwyrzwn l'r . kwnkwl yn qyls'r kwnkwlswz . kwnkwl yn

4827 kwnkwl t' t'pswn l'r :: kwyrm'ksyz pwlm'q kwyrm'k 'wl . kwyr'yyn tymk ny twdswn l'r . kwyrm'k lyk

4928 [ ]d[ ]yp . kwysws swz kwnk[ ] yn twyzwn (l’r) :: "'lqw nwwm l’r nynk 'wyz twyz y . 'mrylmys

\section{Manuscript B (U5643)}

According to the signature T II S, the fragment U5643 originates from Sängim in the Turfan oasis. It deviates in some respects and wordings, but-in contrast to the other three manuscripts (C-E) - follows the same sequence as A.

\begin{tabular}{|c|c|}
\hline 01 & ] ${ }^{3} w 1[$ \\
\hline 02 & ]q t'ryq t'ryr mn: [ ]m'dy \\
\hline 03 & dy'n '[ ]p'nl'ywr mn y'v'lmys kwnkwl lwk \\
\hline 04 & $\mathrm{y}[\mathrm{]}$ y[ ] mn twrwlmys kwnkwl lwk twä[ ] \\
\hline 05 & "rtl'yw pk "wrwr mn s'kyz twyzw [ \\
\hline 06 & lwq ywl swv 'wyz 'swv[ ] ]wr mn [ \\
\hline 07 & ’wypk’ q’äyq̈ lyq [ \\
\hline 08 & $\mathrm{mn}[\quad]$ pws'[ \\
\hline
\end{tabular}

verso

01 'wlwl[ ]kwdy [

02 pylk' [ ]ylykyn 'ydylmys [

03 "l pylyklyk p'qlyä yn [ ]’q]1[

04 m’ä[ ]yq q’nkly 'wyz' t’šwy[ ]r mn n[ ]

05 [ ]n t ' 'wrwr mn p'rč $\mathrm{t}^{\prime}[\mathrm{]}]$ 


\section{Manuscript C}

A Chinese scroll from Toyok ${ }^{13}$ of which three fragments are preserved. They can be arranged in the following order: $\mathrm{Ch} / \mathrm{U} 6402+$ (lacuna) $+\mathrm{Ch} / \mathrm{U} 7455+\mathrm{Ch} / \mathrm{U} 7400$.

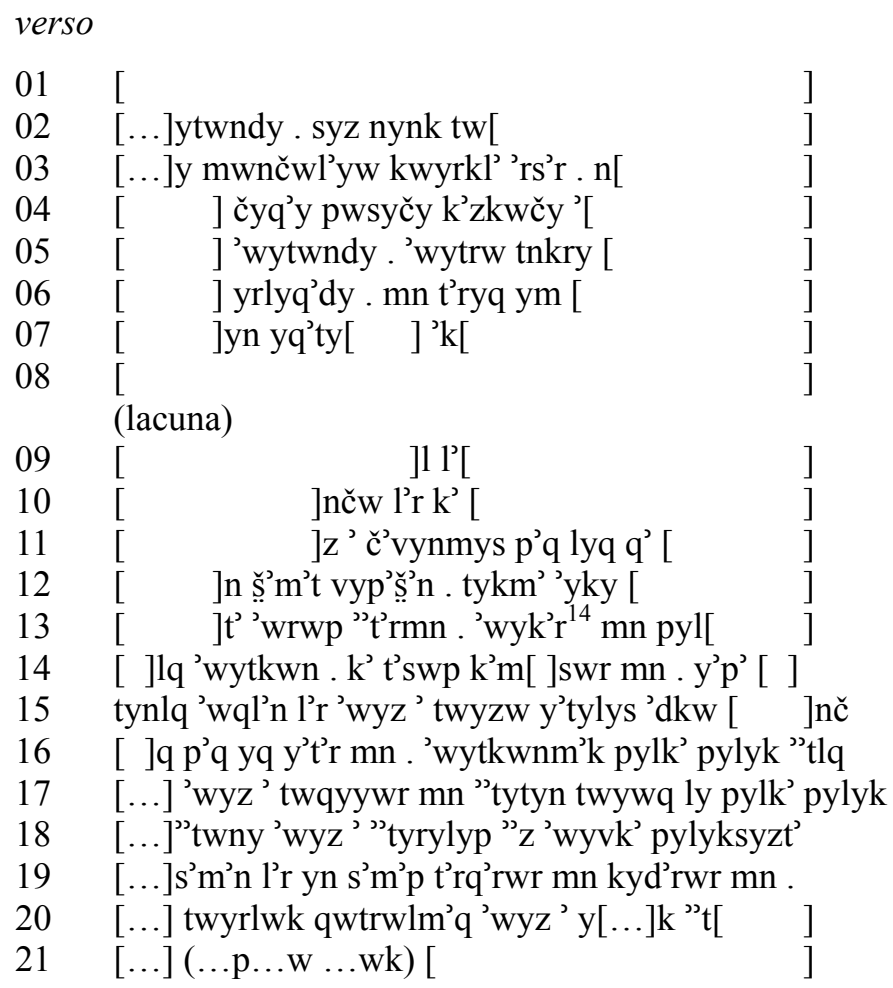

\section{Manuscript D}

As the fragment $\mathrm{Ch} / \mathrm{U} 6673^{15}$ bears no signature that would indicate where it was discovered, the place of its origin is unknown; nevertheless, it is surely from the Turfan oasis.

${ }^{13}$ Recto: T.XVI.665.424c14-17 (lacuna of two columns) c20-25, cf. Nishiwaki 2014: $\mathrm{Ch} / \mathrm{U} 6402$ = cat.-no. 0922; Ch/U7455 = cat.-no. 0923; Ch/U7400 = cat.-no. 0924. According to the old signature T II T 1923 of Ch/U7455r these fragments are from Toyok of the Turfan oasis.

${ }_{14}^{14}$ The long tail of the last letter is unexpected here!

${ }^{15}$ Recto: T.II.100.486c10-14. 


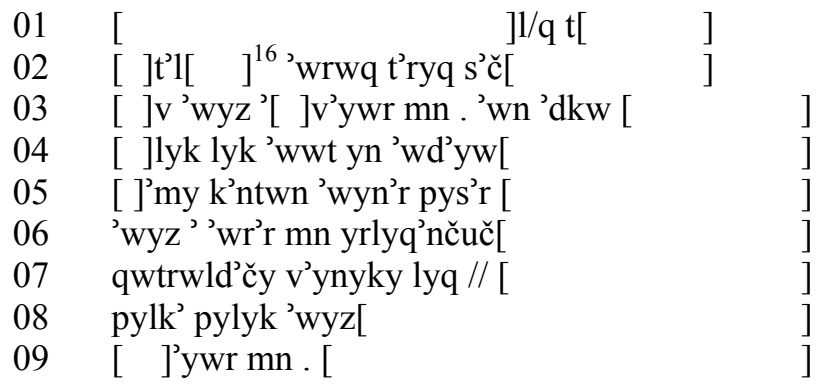

\section{Manuscript $E$}

U5669 ${ }^{17}$ originates from Sängim in the Turfan oasis, it is a poorly preserved fragment from a folding book, only remnants of lines are visible.

recto

011[

$02 \quad p^{3}[$

$03 \quad \mathrm{t}^{\mathrm{k}} \mathrm{k}[$

$04 t^{3} n w[$

05 t’ryq [

06 qylynčy [

07 tynlq $\mathrm{l}^{\prime}[$

08 'wd'ywr mn [

09 lyk 'wrq'q yn 'wr[

verso

01 pylyklyk p'qlyq [

02 qwdrwlm'q [

03 m’nkkw [

04 'wyk'r [

$05 \mathrm{mn}$ [

$06 \mathrm{mn}$ [

$07 \mathrm{t}[$

$08 \quad[$

$09 \quad[$

${ }^{16}$ For a possible reading of two Chinese characters, cf. note 63 .

${ }^{17}$ U5669 (T II S 21.512). According to the old signature, this fragment is from Sängim. 


\section{The text in transcription and translation ${ }^{18}$}

\section{Manuscript A with parallels of the other manuscripts}

\section{First section}

The first of the two sections contains a conversation between a brahman and the Buddha. It is similar to the Kasibhäradvāja sutta which is a talk between a brahman working as a ploughman and the Buddha, who comes to him to beg for food. Before presenting the Uigur text we quote here the essential part of the Pāli sutta in English translation (Norman 2001: 9-10).

Thus I have heard. Once the Blessed One was staying among the Magadhans at Dakkhināgini in the brahman village Ekanālāa. At that time the brahman Kasibhāradvāja's five hundred ploughs were fastened [to the yokes] at the sowing-time. Then in the morning, having dressed himself and taken bowl and robe, the Blessed One went to where the brahman Kasibhāradvāja was at work. At that time the brahman Kasibhāradvāja's food-distribution was taking place. Then the Blessed One went to where the food-distribution [was taking place], and stood on one side. The brahman Kasibhāradvāja saw the Blessed One standing there for alms, and said this: 'I, ascetic, plough and sow, and when I have ploughed and sown I eat. You too, ascetic, should plough and sow, and eat when you have ploughed and sown.' 'I too. brahman, do plough and sow, and when I have ploughed and sown, I eat.' 'But we do not see the venerable Gotama's yoke, or plough, or ploughshare, or goad, or oxen, but nevertheless the venerable Gotama speaks thus: "I too, brahman, do plough and sow, and when I have ploughed and sown, I eat". Then the brahman Kasibhāradvāja addressed the Blessed One with a verse.

76. 'You say you are a ploughman, but we do not see your ploughing. Being asked, tell us about your ploughing, so that we may know your ploughing.'

77. 'Faith is the seed, penance is the rain, wisdom is my yoke and plough; modesty is the pole, mind is the [yoke-]tie, mindfulness is my ploughshare and goad.

78. I am guarded in body (and) guarded in speech, restrained in my belly in respect of food. I make truth my weeding-[hook], [and] meekness my unyoking.

79. Energy is my beast of burden; bearing me to rest-from-exertion it goes without turning back to where having gone one does not grieve.

\footnotetext{
${ }^{18}$ Here in this part, the line numbers are given according to the two sections as index numbers in bold script.
} 
80. Thus is this ploughing [of mine] ploughed. It has the deathfree as its fruit. Having ploughed this ploughing one is freed from all misery.'

One gets the impression that the Old Uigur text is essentially based on the Pāli text. The ploughman advises the Buddha that he should also take tools for working in the field. In his response, the Buddha tells him that he has his own field to work, which is his teaching truth to the people. In the similes for explaining his qualities and activities, he makes wide use of the agricultural terminology, but some terms are either not clear or do not belong to the lexicon of field work. As a whole, these similes give us a deep insight to an important side of daily life. Thus one can safely conclude that it is an original text composed by a Uigur insider. The framework is, of course, a Buddhist scripture, but the arrangement and formulation is of an immanent local character. It is possible to characterise this text as a free translation of the sutta or another text based on it that we do not know.

${ }^{01}$ [ ] ] braman-a m(ä)n ärsär mahavan gạ ögüztä üstün akar ögüzlärtin kedin arku ${ }^{02}$-ta salkım suvta tururm(ä)n amrılmıš bäk mängü atl(1)g balıkım ol akmaksız artamaksız atl(1)g ${ }^{\mathbf{0 3}}$ balıkım ol m(ä)n ärsär kändü yetinčsiz tutunčsuz atl(1)g ärürm(ä)n ulug bilgä biliglig ${ }^{04}$ sögüt altınınta tınmıš ärürm(ä)n tep yarlıkadı ::

[The Buddha] ventured to say: 'Oh, brahman! I live in a valley (near) the cold water west of the flowing rivers above the Ganges river of Mahāvana. My city is called "calm, firm, everlasting". My city is called "Not-flowing, not destroyable". I am called "not reachable, not keepable". I take a rest under the tree of great wisdom.'

The Pāli text mentions the Buddha's place as 'among the Magadhans at Dakkhināgiri in the brahman village Ekanālāâ' (Norman 2001: 8). 'Dakkhiṇāgiri lay to the south of Rājagrtha beyond the hills that surrounded the city' (DPPN). This does not correspond to the probably rather fictitious name of the Old Uigur text, since there were several forests called Mahāvana, but none of them (DPPN) corresponds to the place mentioned above. All these mean that the setting is totally different, which is an argument against a direct dependence on the Pāli text, as the anonymous reviewer rightly pointed out. Anyhow, the praise of this place where the Buddha lives seemingly does not impress the brahman as we can see from the next passage.

ötrü braman inčä tep ötünti ${ }^{05}$ bilgä tendar-a sizin ${ }^{19}$ turguluk olurguluk yeriniz suvuyuz munı munčulayu sukančig ${ }^{20}$ ärsär ${ }^{06}$ nä üčün tarıg tarımazsiz munı̀ täg irinč čigay

\footnotetext{
${ }^{19}$ Ms. C 02 has sizniך.

${ }^{20}$ Ms. C 03 körklä.
} 
bušıčı koltgučı ${ }^{21} \operatorname{tınl}(1) g$ käzigintä ${ }^{07}$ aya patır ${ }^{22}$ kötürü kıy käzä kapıs sanayu .. bušı pinvat kolu yorırsiz tep ötünti ::

Then the brahman deigned to speak: 'Oh, wise priest ${ }^{23}$ ! If your place ${ }^{24}$ where you stand and sit is so wonderful like this, why do you not cultivate land and why do you-like those in the chain of poor beggarsinstead take the alms bowl and go around the streets and doors asking for alms food?'

In Sn 76 the brahman simply asks the Buddha to explain his manner of ploughing.

(c)

${ }^{08}$ anta ötrü tükäl bilgä biliglig tänri tänrisi inčä yarlıkadı bramana ${ }^{09}$ mänin tarıglag yerim ärsär antag ol bilig berig kögüz atl(1)g yerim tolp kamag tınl(1)g oglanlarıg ${ }^{10}$ ozgurgalır kutgargalır üčün ${ }^{25}$

After that the completely wise god of gods ventured to speak as follows:

'Oh, brahman! My field of cultivation is such a place called "Knowledge-giving Mind" 26 . In order to free and liberate all human beings:

(d)

After this introduction, the text continues with a list of qualities and activities of the Buddha for the redemption of the beings given in various similes. The phrases are often structured according to the rules of internal verse alliterations, e.g. [2] sa- ... sa- ... sa- ...; [3] ya- ... ya- ... ya- ...; [4] a- ... a- ... a- ...; [5] tu- ... tu- ... to- ...; [13] ya- ... ya- ... ya- ... ya- ...; [15] ta- ... ta- ... ta- ...; [17] a- ... a- ...; [19] ta- ... ta- ...; [20] la- ... la- ...; [23] kö- ... kö- ... Not rare are also figurae etymologicae like in [3] yapırgu (üzä) yapır-; [6] suvın suva-; [7] otın ota-; [9] orgak (üzä) or-; [10] baglıkın bagla-; [20] laklak (üzä) lakla-).

${ }^{21}$ Ms. C 04 käzgüči (?) 'one who wanders around', it can be a new word for a beggar who wanders around. Not attested with this meaning so far, cf. Modern Turkish gezici.

${ }^{22}$ The compound aya pattr is not recorded yet. Cf. aya 'palm' in UWN II.2: 67-68. One could imagine a mistake for ayak patır which is also not recorded as a real word pair according to UWN II.2: 75-76. The Sanskrit word is not pattra as given there on p. 76, but pātra 'bowl' (cf. SWTF III: 113b). From Mongol texts where badir aya -a is known, one surely can conclude that Old Uigur had a compound patır ayak, too.

${ }^{23}$ The use of tendar < mp. dēndār 'priest' in addressing the Buddha is known from the Devatāsūtra, cf. Zieme 2016: 374.

24 'land and water'.

${ }^{25}$ The first line of ms. B has only a few traces of letters at its end ( $\left.[\quad] m o l\right)$, but they do not concord to ms. A.

${ }^{26}$ The term has not been encountered so far. The second word berig is a theoretically possible formation from the verb stem ber- 'to give', but not known. The anonymous reviewer suggested a possible mistake for *berigli 'giving', which would be preferable from a grammatical point of view. 
[01]

A ädgü kılınčlıg urugug sačarm(ä)n

I spread the seed of good deeds.

B [ädgü k1lınčlıg uru]g tarıg tarırm(ä)n

I sow the seed ${ }^{27}$ [of good deeds].

Sn 77 saddhä bijam 'Faith is the seed'.

One can argue that 'faith' is the cause of 'punya'. Moreover, it is remarkable that the Uigur author interprets the statement in a complete phrase by adding a predicate of action.

[02]

A šamat ${ }^{28}$ vipašan atl(1)g sanbarım üzä ${ }^{11}$ sapanlayurm(ä)n

I plough with my equipment ${ }^{29}$ called śamatha and vipaśyanā.

B [sa]madi dyan-[lig sanbar üzä s]apanlayurm(ä) $n^{30}$

I plough [with the equipment] of samādhi dhyāna.

Sn 77 tapo vutthi 'penance is the rain'. In the Uigur text, there is no phrase with 'rain'. The next phrase in Pāli is connected to ploughing: Sn 77 pañña me yuganangalam 'wisdom is my yoke and plough'. The Uigur version mentions the main poles of meditation (dhyāna as in B), śamatha and vipaśyanā, but not pañña = prajñā 'wisdom'. In a commentary, the author compares the seed [01] as the root of discipline and the plant as [02] 'śamatha and vipaśyanā'.

\section{[03]}

A yavalmıš köyüllüg yapırgum ${ }^{31}$ üzä yapırurm(ä)n $n^{32}$

With my blanket of calm mind I cover them.

B yavalmıš könül-lüg y[apırgum üzä] y[apırur]m(ä)n

[With my blanket] of calm mind I c[over] them.

${ }^{27}$ Differently from A the variant uses the compound urug tarig, and the verb tarl- fits better to the agricultural terminology.

${ }^{28}$ The word is spelled $s^{\prime} m{ }^{\prime} p^{\prime} t$, which can be read šamapat. This could be explained as a loan from Skt. samāpatti (Chin. sanmobodi 三摩鉢底) 'attainments' (a term of meditation), but here it is a mistake for šamat < śamatha (cf. DDB etc.).

${ }^{29}$ The word sanbar (Skt. sambhära, SWTF IV: 328) is a Buddhist term which comprises all equipments or means leading to salvation.

${ }^{30}$ The verb is sapanla- 'to plough', in B with a dotted /n/.

${ }^{31}$ The word yapirgu is not known so far, as a derivation form yapir- one may suggest a meaning like 'cover' or 'blanket'. Cf. SI 1863 verso 06-07 kllınč-lıg tämir yapırgun [...] : ölümlüg šaktin bičllu: 'with the iron yapırgu of karma [...], cut with the śakti of death'.

${ }^{32}$ yapur- = yapur- 'to smoothe and level' (ED: 879a). An alternative solution can be envisaged if one considers the word pair yanč-yapir-attested in an Ägama text as equivalent of Chinese canmie 殘滅 ‘to crunch’ (Wilkens 2017: 236). 
Apparently, there is no difference between the two versions. Sn 77 hiri $\bar{\imath} \bar{a}$ ' modesty is the pole'. There is no direct connection to the Uigur phrase, but the exact meaning of yapirgu is not clear. Perhaps the next Pāli phrase fits better: Sn 77 mano yottam 'mind is the (yoke)-tie'.

\section{[04]}

A amrılmıš köyüllüg atızın arıkın ${ }^{12}$ uz etärm(ä)n

I appropriately cultivate the field and canal of the peaceful mind.

B -

This phrase is apparently omitted in version B.

\section{[05]}

A turulmıš könüllüg tugın urukın bärkürü tokıyurm(ä)n

I weave firmly ${ }^{33}$ the barrier ${ }^{34}$ and lasso of the settled mind.

B turulmıš köjüllüg tug[1n] artlayu b(ä)k ururm(ä)n

I firmly ${ }^{35}$ and strictly put up the barrier of the settled mind.

Some essential words differ between the two versions, but the content is the same. $\mathrm{Sn}$ 77 sati me phālapācanam 'mindfulness is my ploughshare and goad'.

[06]

A üč kutrulmaklıg yul suvin ${ }^{13}$ suvayurm(ä)n

I water with the lake water of the three redemptions.

B säkiz tözü[n yol]lug yul suv üzä suva[y]urm(ä)n

I water with the lake water of the eight noble [ways].

While the metaphor is the same in both manuscripts, the members are different. 'The three redemptions' of A is equal to 'the eight noble ways' of B. Both are used in many dogmatic contexts, but the eightfold noble way is much more widespread. One should also note the difference in the structure of the instrumental case expressed by the suffix in A and by the postposition $\ddot{u} z \ddot{a}$ in B. The compound $y u l s u v$ is not known as such from other sources, but there are some examples of yul suvl 'Quellwasser' (Wilkens 2013: 424).

${ }^{33}$ More common is the shortened form bäkürü 'firmly'.

${ }^{34}$ In A the words tug and uruk should have similar meanings, but has not been met with so far as a compound or word pair. In B only $t u g$ is used. For $t u g$, the anonymous reviewer suggested the usual meaning 'flag, standard', which would be closer to uruk 'lasso'.

${ }^{35}$ The verb artla- is registered by Mahmūd al-Kăšgarī with the example ol anı artladı 'he slapped him on the back of the neck' (ED: 209b), but this does not fit here. M. Erdal suggested a derivation from art 'mountain pass' in the sense of 'like a mountain pass' = 'firmly'. 
[07]

A ünä kälmiščä ööčlüg käklig agulug otın otayurm(ä)n ${ }^{36}$..

I enflame with the poisonous fire of malice and spite whenever it appears.

B [...] öpkä kakıg-lıg [... otın otayur]m(ä)n

I $[\ldots \ldots]$ the anger and rage $[\ldots]$.

[08]

A üč türlüg ${ }^{14}[\mathrm{a}]$ gu tüši tämi uz ušap özin ${ }^{37}$ ök bošar itilür

The fruits of the three poisons become appropriately crushed ${ }^{38}$, empty ${ }^{39}$ by themselves and disappear ${ }^{40}$.

B [ ] boša[ ] ulul[ ]güdi [ ]

Version B has only a few imperfect words that do not allow a complete translation.

[09]

A yiti sikiz bilgä biliglig orgakım üzä ${ }^{15} \operatorname{orarm}(a ̈) n$

With my sickle of sharp wisdom ${ }^{41}$ I cut (them).

B [yiti ..] bilgä [bi]ligin etilmiš [orgakım üzä orarm(ä)n]

[With my sickle] built of [sharp] wisdom [I cut (them)].

Interestingly, we can see here a difference only in the construction of the 'sickle'. In B the verb etil- is used. In [10] we can see that version A has a similar construction with yarat-.

[10]

A alın čävišin yar(a)tmıš baglıkın bäk baglayurm(ä)n

With a strap ${ }^{42}$ made of skilful means I bind firmly.

B al biliglig baglıkın [bag]l[ayurm(ä)n]

With a strap of skilful means [I bind].

The 'skilful means' is al čäviš in ms. A and al bilig ${ }^{43}$ in B, and they are equivalent with Skt. upāya ${ }^{44}$. In ms. E we emended the text according to ms. B.

${ }^{36}$ ota- is a variant to otla-, cf. ED: $42 \mathrm{~b}$.

${ }^{37}$ Spelled 'wsyn.

${ }^{38}$ The verb $u \check{s} a$ - is a variant of $u v \check{s} a$ - 'to become crumbled, crushed' (ED: 16b).

${ }^{39}$ The verb boša- is a younger form of bošu- 'to be empty' in Čagatay (cf. ED: 377b).

${ }^{40}$ itilür may be explained as a variant of yitilür 'it is going lost'.

${ }^{41}$ It could also mean 'with the sharp sickle of wisdom', 'sharp' is expressed by the word pair yiti sikiz.

${ }^{42}$ The word baglık 'strap' (cf. Sevortjan 1978: 17 and especially kamass pālu 'Riemen, Band, mit dem der Stiefel am Fussgelenk angebunden wird', cf. Donner 1944: 50b, by Sevortjan regarded as a loanword from a Turkic language) is a perfect equivalent for Pāli yotta 'the tie of the yoke of a plough or cart'.

${ }^{43}$ For both terms cf. UWN I.1: 84-85.

${ }^{44}$ Pye 2003; DDB and other dictionaries. 
[11]

A kutrulmaklıg kaylım üzä tašuyurm(ä)n

With my carriage of redemption I carry (them).

B [kutrul]mak[1]1g kaylı üzä tašuy[u]rm(ä)n

With the carriage of [redemption] I carry (them).

In $\mathrm{B}$ the carriage is not personalised.

[12]

A ${ }^{16}$ mängü yaruk atl(1)g nirvanlıg örtgüntä ügärm(ä)n

On the threshing place of the nirvāna called 'Everlasting light' ${ }^{45} \mathrm{I}$ heap up.

B ni[rv]an[lıg örtgün]tä ururm(ä)n

On the threshing place of the $n$ [irvāna] I winnow.

The two phrases use different predicate verbs: A $\ddot{u} g$ - 'to heap up', B ur- 'to winnow'.

\section{[13]}

A yapada yadılmıš yarlıkančučı könüllüg eligim ${ }^{17}$ üzä yadarm(ä)n

With my hand of mercy spread out over all I spread out.

B barčata [yadılmıš yarlıkančuč1] könüllüg elgim ${ }^{46}$ üzä bagın [...m(ä)n]

With my hand of [mercy spread out] over all [I ...] their fetters.

\section{[14]}

A üč kölüngütäki udlarıg ${ }^{47}$ tulukka košarm(ä)n

I harness the cows of the three vehicles to the stone roller.

B [ ] kö[yül]lüg tuluk[ka košarmän]

Version B is too defective to give a complete translation, but it is worth noting that the word tuluk 'stone-roller' is preceded by an attribute which seems to be missing in version A. In the Pāli text there is no item that could be interpreted as 'stone-roller'.

\section{[15]}

A tavranmaklıg tal kamčı üzä ${ }^{\mathbf{1 8}}$ tavratı sürärm(ä)n

I drive (them) extensively with the willow whip of moral action.

B [ ] up [

${ }^{45}$ The 'everlasting light' is an interesting notion for the nirvāna known also from the Garbaparimocana sūtra, edited in Zieme 2005: H217.

${ }^{46}$ The difference between eligim in A and elgim in B shows existing variants in language use.

${ }^{47}$ The spelling ' $w w t$ is very strange for $u d$ 'cow'. 
[16]

y1lig yumšak bolmıšta yinin igidin yararm(ä)n

When it becomes warm and soft I split with body (?) and [ ] (?) ${ }^{48}$.

adıra berdäči äsinkä altı tiš ${ }^{19}$-lig čapčam üzä sačarm(ä)n

Against the separating wind ${ }^{49}$ I winnow with my fork of six tines ${ }^{50}$.

[18]

yiv(i)lmišs ${ }^{51}$ bilgä biliglig yügäkin ${ }^{52}$ yodanın turgururm(ä)n

I set up the box and the bow $(?)^{53}$ of trained wisdom.

taldurmaklıg ${ }^{54} \operatorname{tarmakım}^{55} \ddot{\text { üzä }}{ }^{20}[\quad-\mathrm{m}(\ddot{a}) \mathrm{n}]$

With my rake of exhausting [I

[20]

[ ] köyül-lüg yalkok ${ }^{56}$ laklakım üzä laklayurm(ä) ${ }^{57}$

I lick (them) with my saliva licking of the [ ] mind.

${ }^{48}$ Despite the clear spelling yinin igidin, it is difficult to understand this sequence. If $y$ in is 'body' (or yin 'dung' [ED: 941a]?), what could be igid? If igid were 'wrong', what could be yin? We cannot offer a plausible solution.

49 äsin means 'breeze, gentle wind' (ED: 248), but here it is more generally used for 'wind'.

${ }^{50}$ This describes the procedure of winnowing. A winnowing fork has usually flat wooden tines, here six tines (altı tiš). The fork as a whole is called čapča, cf. the Old Uigur 'Erntesegen' (Molnár and Zieme 1989: 149) with references to Modern Uigur dialects. Instead of forks, winnowing-baskets or winnowing fans were more often used in China (Bray 1984: 363-381). According to Golomb only winnowing shovels were used (Golomb 1959: 88), but A. Yakup (personal communication) has assured us that forks with tines were common; they are called either čapča or ara, depending on the region of today's Xinjiang.

${ }_{51}$ yivil- 'to be equipped, to be trained' (ED: $877 \mathrm{~b}$ ). meant here.

52 yügäk, cf. ügäk 'box' (ED: 105). Unfortunately, we cannot explain what kind of box is

${ }^{53} \mathrm{Cf}$. Zieme 2019 , with a discussion of the unknown word $y w d$ ' $n$ which seems to be the same as here referring to it as a variant of yatan 'a wooden bow', 'the bow-shaped implement with which raw wool is worked' (ED: 892a).

${ }^{54}$ taltur- or taldur- 'to exhaust' (ED: 494; Róna-Tas, Berta and Károly 2011: 841-846, s.v. táltos) with a possible semantic extension 'causing meditation'.

${ }_{55}$ tarmak (ED: 549-550) is a word resembling some forms of tıryak 'claw' (ED: 551b), but originally may be different from it as G. Clauson (ED: 551b) declares. Here it must mean some kind of object similar to Teleut tarmak 'rake' or Türki tarmak 'harrow', both quoted in ED.

${ }_{57}^{56}$ yalkok, cf. Zieme (in preparation): text 16.

${ }^{57}$ laklak or laglag. It seems that the word is of onomatopoetic origin. Radloff mentions Ottoman لقلاق laqlaq 'das Schnalzen mit der Zunge' (Radloff 1905: 729), but here it is rather 'licking'. 
[21]

eyin ögirmäklig ädgüm üzä ${ }^{21}[\quad$-m(ä)n]

[I ] with my virtue (or: knife? $)^{58}$ of joy for others. ${ }^{59}$

[22]

[ ] ] sač ariglayurm(ä)n

I clean the frying-pan [ ]

[23]

köni nomlug körüm[lüg … üzä $\quad-m(a ̈) n]$

[ ] ] the [ ] of the view of the true dharma.'

Comparison of [1] to [14] in the two manuscripts $A$ and $B$ highlighting the main differences in bold script

The other manuscripts deviate much more from A and B.

No. Dunhuang text

01 ädgü kılınčlı urugug sačarm(ä)n

02 šamapat vipašan atl(1)g sanbarım üzä sapanlayurm(ä)n

03 yavalmıš köyüllüg yapırgum üzä yapırurm(ä)n

04 amrılmıš könüllüg atızın arıkın uz etärm(ä)n

05 turulmıš köyüllüg tugın urukın bergürü tokıyurm(ä)n

06 üč kutrulmaklıg yol suvın suvayurm(ä)n

07 ünä kälmiščä ööčlüg käklig agulug otın otayurm(ä)n

08 üč türlüg agu tüši tämi uz ušap özin ök bošar itilür

09 yiti sikiz bilgä biliglig orgakım üzä orarm(ä)n
Sängim text U5643

[ädgü kılınčlıg uru]g tarıg tarırm(ä)n

[sa]madi dyan [ üzä

sa]panlayurm(ä)n

yavalmıš köyüllüg y[apırgum üzä]

y[apırur]m(ä)n

turulmıš köyüllüg tug[In] artlayu b(ä)k ururm(ä)n

säkiz tözü[n yol]lug yol suv [ü]zä

suva[y]urm(ä)n

[...] öpkä[lig k]akık-lıg [ ... otın otayur]m(ä)n

[ ] boša[ ] ulul[ ]güdi [

[yiti ..] bilgä [bi]ligin etilmiš [orgakım üzä orarm(ä)n]

${ }^{58}$ ' $\mathrm{dkw}=\ddot{a} d g \ddot{u}$ 'good, virtue', but one could expect a quite different word denoting a kind of concrete object, as e.g. a metathetical form *ädgü from $\ddot{a} g d \ddot{u}$ 'a curved knife' (ED: 102b; UWN II: 170). 隨喜.

${ }^{59}$ The Sanskrit term of eyin ögirmäk, literally 'following joy', is anumodana $=$ Chin. suixi 
No. Dunhuang text

10 alın čävišin yar(a)tmıš baglıkın bäk baglayurm(ä)n

11 kutrulmaklıg kạlım üzä tašuyurm(ä)n

12 mäygü yaruk atl(1)g nirvanlıg örtgüntä ügärm(ä)n

13 yapada yadılmıš yarlıkančučı köyüllüg eligim üzä yadarm(ä)n

14 üč kölüngütäki udlarıg tulukka košarm(ä)n
Sängim text U5643

al biliglig baglıkın [bag]1[ayurm(ä)n]

[kutrul]mak[1]1g kaylı üzä tašuy[u]rm(ä)n

$n$ [irvanlı] $\ddot{\text { ort }}] \mathrm{g}[$ ün]tä ururm(ä)n

barčata [yadılmiš yarlıkančučı]

köyüllüg elgim üzä bagın [yadarm(ä)n]

[ ] kö[nül]lüg tuluk[ka ]up

Manuscript $\mathrm{C}$ has a different order $(=\mathrm{A} \ldots,[02], \ldots,[13] \ldots,[05], \ldots,[06], \ldots)$, and not all items can be identified or compared to those of ms. A.
$\begin{array}{ll}{[? ?]} & { }^{09}[ \\ {[? ?]} & 11\end{array}$
a]1-1[1g
]$^{10}[$
iri]nčü-lär-kä [
ü]zä čävinmiš ${ }^{60}$ baglıkka [ ] ${ }^{12}[$
]män .
[02] šamat vipašan . tegmä iki [türlüg] ${ }^{13}\left[\ldots\right.$. -ta urup atarmän ügärm(ä)n $n^{61}$
[??] bil...... ${ }^{14}$...1.g ötgünkä tašup käm[i]šürm(ä)n .
[13] yapa [ ] ${ }^{15}$ tınl(1)g oglanlar üzä tüzü .yadılmıš ädgü [k1l1]nč ${ }^{16}[11] g$ bagıg yatarm(ä)n .
[05] ötgünmäk bilgä bilig atl(1)g ${ }^{17}[\ldots]$ üzä tokıyurm(ä)n
[??] atıtın tuyuglı bilgä bilig ${ }^{18}[\ldots]$ natunı(?) üzä adırılıp az övkä biligsiztä ${ }^{19}[\ldots . .$.$] saman-lar-1n samap { }^{62} \operatorname{tarkarurm}(\ddot{a}) n$ kitärürm(ä)n .
[06] ${ }^{20}$ [üč] türlüg kutrulmak üzä yivig at....

Manuscript D (Ch/U6673) has a different order:

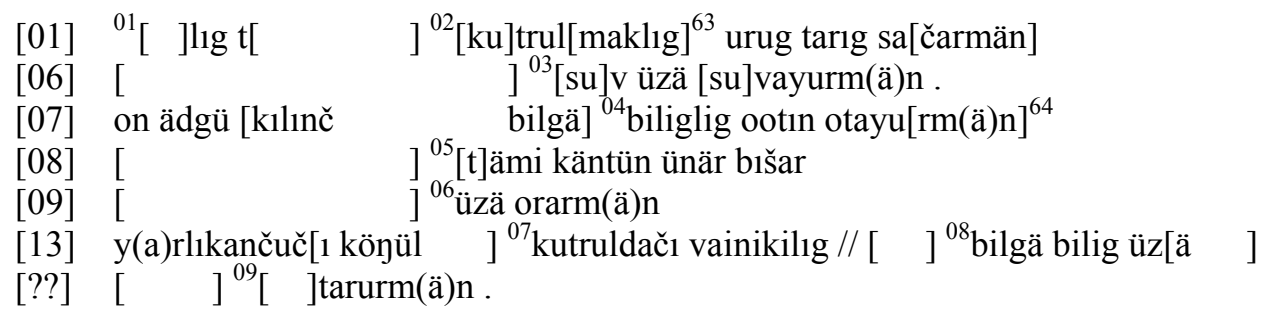

${ }^{60}$ Or $\check{c} a v i n m i \check{s}$, unclear.

${ }^{61}$ The last letter -r seems to have a long tail wherefore a different reading might be possible.

${ }^{62}$ Not translated here. M. Erdal suggested a verb *sama-, the stem of saman 'straw'.

${ }^{63}$ The letters are similar to the Chinese characters [...] 八 (?) 一.

${ }^{64}$ The predicate of the phrase corresponds to no. [07], but this is doubtful, because the sentence begins with the compound ädgü [kllinč] 'good deeds' augmented by on 'zehn' which appears only in no. [1]. 
Manuscript E (U5669)

The predicate of the phrase corresponds to no. [07], but this is doubtful because the sentence begins with the compound $\ddot{a} d g \ddot{u}$ [kllınč] 'good deeds' augmented by on 'ten', which appears only in no. [1]. Among the manuscripts, A parallels [07] and [09] in ms. E no. [08] is missing.

As far as it can be judged by the remnants, the order is nearly the same as in ms. A.

[07] ${ }^{07}$ tınlg-lar [ ] ${ }^{08}$ otayurm(ä)n

[09] y[iti bilgä bilig] ${ }^{09}$-lig orgakin or[armän .]

[10] [... al] ${ }^{\text {verso } 01}$ biliglig baglik[1n baglayurmän .]

[11] ${ }^{02}$ kutrulmak-[lig kaylı üzä tašuyurmän .]

[12] ${ }^{03}$ mängü [nirvanlıg örtgüntä] ${ }^{04}$ ügär[män .]

$\begin{array}{ll}{[][} & ]{ }^{05} \mathrm{~m}(\ddot{\mathrm{a}}) \mathrm{n} \\ {[\mathrm{C}]} & ]{ }^{06} \mathrm{~m}(\ddot{\mathrm{a}}) \mathrm{n} \\ \left.{ }^{0}\right][ & ] \\ { }_{\mathrm{t}}^{08}[ & ] \\ { }^{09}[ & ]\end{array}$

\section{Second section}

Since there is a long gap between the two sections in A, it is not secure how they are related to each other. It is possible that the Buddha continued his preaching about his doctrine. But since the quatrains rather contain the tenets of the Mahāyāna way, it is difficult to see its direct relation to the first section of the manuscript. The Pâli Kasibhäradvāja sutta, which can be regarded as the original text on which the Old Uigur version of the first section is based, is rather short; the remaining part of the sutta with its mysterious story of the bowl of milk rice had its place in the long lacuna of the manuscript.

Thus, one cannot exclude the possibility that the second section was a separate work within a miscellany. In contrast to section one, there are also no other manuscripts that contain the stanzas of this second section.

The quatrains have the typical metrical structure of Buddhist verses that was widespread among the Old Uigur monks and possibly also among lay people. The strophic alliteration is regular and the syllable numbers follow typical patterns from 7 to 12 syllables. There is no real end rhyme, but a certain pattern ( $\mathrm{a} \mathrm{b} \mathrm{c} \mathrm{b}$ ) is prevalent. 
D0583V+D0581V+D0582V (directly joined)

[Quatrains about Mahāyāna tenets culminating in the equation of the Buddha with the mind (citta-buddha $=$ buddha-citta) $]$

[01]

${ }^{01}$ [yi ]n bolmıšın körzünlär

yertinčü[ ] ${ }^{02}$ körmäz mü ..

yetmištä ök üdi kolus1 ..

yitlinip yal[

One should see that [ ]

Does one not see that the world [ ]?

If time and moment arrived,

it vanishes [ ].

[02]

[ $\quad]^{03}$-miš amrak ogul kız..

yıglašip sıgtašip kalmaz mu ..

yinčürüp körmädin ärd[ ]

${ }^{04}$ yertinčü uvutı ärmäzmü ::

[Beloved] dear son and girl:

does not remain (nothing than) weeping and mourning together?

Bowing down, without seeing [ ],

is it not the shame of the world?

[03]

kertgüngü kärgäk buyanka ..

kirsiz tüšlärig [

${ }^{05}$ kirsärbiz yama tamuta ..

ketmäz bizni birlä birgärü barıšur ::

One should believe in (making) punya,

the stainless fruits [ ].

If we enter the hell (ruled by) Yama ${ }^{65}$,

none comes out who is going with us together.

[04]

ketärip alku ämgäk [ ] ]

${ }^{06}$ kičmädin mänikä tägürür ..

kertü čın burhan otlag iš-lärin ..

kenindä otgurak bol[

${ }^{65}$ There is no hell called yama, but since Yama is the king of hells, one should interpret here as 'hell (ruled by) Yama'. 
Removing all [ ] pain [ ]

without delay it leads to happiness.

The true Buddha [will do (?)] the pasture works later surely [ ].

[05]

${ }^{07}$ özirkänmiščă ${ }^{66}$ amraklar ..

ölmištä birlä barıšmaz ..

öz ät’öz tugurdačı [ ]

${ }^{\mathbf{0 8}}$ üzüt tep korkar yagumaz ::

When the beloved ones regarded as one's selves

die, one does not go with them together.

[ ] giving birth the own body

he fears that it is the soul does not approach to it ${ }^{67}$.

[06]

09.̈zinin kazganmı̌s äd tavar ..

öyikä kalır tusulmaz ..

öz ät ${ }^{2} z^{68}$ [

${ }^{10} 0$ üküš ašunta ketišmäz ::

The wealth gained by oneself

remains for others, it has no profit.

The own body [

in many existences one does not part together ${ }^{69}$.

[07]

anın amtı bilgälär ..

artuk k1lzunlar buyanıg

[arit1 $^{70}{ }^{11}$ k1lmagu bidat1 ..

alp ärür yalnuk ašunı ::

Therefore now, oh wise men!

Do more punya!

not [at all] doing it in vain,

difficult (to obtain) is the existence of humans.

\footnotetext{
${ }^{66}$ The verb özirkän- 'to regard as one's self' (Erdal 1991: 611) has been known so far from three examples.

${ }^{67}$ This translation of the sentence was suggested in a personal communication by M. Erdal.

${ }^{68}$ Perhaps the word beginning with $t y l[\ldots]$ of the preceding line should be added here, but because of the damage, this remains unclear.

${ }^{69}$ The verb here is ketiš- 'to part from one another', cf. Erdal (1991: 561) with one example only.

${ }^{70}$ The anonymous reviewer suggested the emendation artt.
} 
[08]

adrılsarbiz [öz ä]töztin

[a ]

12 ančulayu ärür ok (?) sudak1 ..

al lenhua oot ičindä

If we separate from our own body

[ ].

Thus it is like in the water

a scarlet lotus plant.

[09]

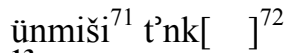

${ }^{13}$ ärtinü alpın alzunlar ..

ämgänip tapmıš yalıuk

ät’öz [ ] ${ }^{14}$ ukzunlar ::

[ ]

one should accept (that getting a body) is very difficult.

One should understand that the body of a being

received under sufferings [is transitory].

[10]

ärtimlig yilinü ät’öznin ..

ärtims $[i z$

[ ] ${ }^{15}$ tınl(1)g uguš1 ..

enčgülüg nirvanka tägzünlär [::]

Attached (?) to transitoriless [ ]

[ ] of the transitory body;

[ ] the clan of humans

they will reach the peaceful nirvāna!

\section{[11]}

$[\mathrm{kö}] \mathrm{s}[$
${ }^{16}$ könül tözintä

kök kalık täg [ ]yks[ ]

${ }^{17}$ körki yok öni b(ä)lgürmäz ::

${ }^{71}$ A short word beginning with ä- is missing.

${ }^{72}$ Unclear.

${ }^{73}$ Prajñāpāramitā texts often refer to the contrast of tuy(un)mak 'to perceive' and yayılmak 'to err', cf. Tekin 1980: 35: ančulayu ymä 心' [köyül] tözin tuysar köyül tuydačr bolup tuyunmak

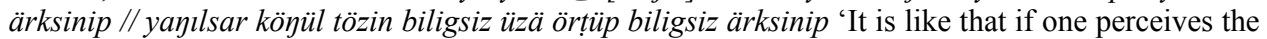
essence of the mind, one becomes one perceiving the mind being mighty of perceiving; if one errs about the essence of he mind, one is covered by nescience and nescience becomes mighty'. 
[

In the essence of the mind there is nothing.

Like the heaven [ ]

There is no form, no colour appears. ${ }^{74}$

[12]

körgülük sakınčıg öritsär .

köyülin [

[kö ] ${ }^{18}$ b[arč]a b(ä)lgürüp .

közüngäy ondın sıjar t(a)vraksiz ::

If one arouses the thought of seeing

with the mind [

[ ] all appears

and will be seen in the ten directions without haste.

\section{[13]}

ädgüti yinčürüp könülin .

ädgükä ayıgka ${ }^{19}$ täprämä . ${ }^{75}$

ädgüli ayıglı kılınč tüši bar .

ärürin ärmäzin edärmä ::

Appropriately bowing down with the mind

do not move to good or evil!

Good or evil deed has a fruit,

do not pursue that what exists and that what does not exist!

\section{[14]}

išidmiš ün y(a)Đku ol .

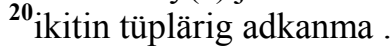

etigsiz tözkä inangıl .

etiglig noomta ${ }^{76}$ ornanma ::

The voice heard is an echo.

do not attach to both foundations!

Do not believe in the unaggregated essence!

do not settle in the aggregated dharma!

\section{[15]}

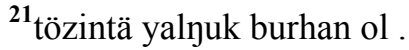

tuymamıš üdün ämgänmä .

${ }^{74}$ Both nouns have the possessive suffix of the 3rd person.

${ }^{75}$ The spelling with final $-\mathrm{k}$ is apparently a mistake.

${ }^{76}$ nom in the rare spelling $n w w m$, cf. 1. 28 . 
tolun bütmiš tözi bar .

tuyunmıš ${ }^{22}$ üdün sävinmä ::

In essence, (each) creature is a Buddha.

Do not worry in the time of not having perceived.

The fully completed one has an essence.

Do not be delighted in the time of perceiving!

\section{[16]}

tuymak yạılmak ikigünün

tözi kurug ol atama .

tözi kurugnıy čin ${ }^{\mathbf{2 3}}$ tözin

tuymaksız tuyurur sävinmä ::

Do not call that the essence

of perceiving and erring, the two are empty.

Do not be delighted that not-perceiving lets you perceive

the true essence of that of which the essence is empty!

\section{[17]}

sakınıp yinčürsär ädgüti .

sansartın öni irak yok .

${ }^{\mathbf{2 4}}$ sakinčsiz bolsar közünür .

sakınč üküškä burhan yok ::

If one venerates while appropriately reflecting

one is not far from the samsāra.

If one is not reflecting, (the Buddha) appears.

Because of having many reflections there is no Buddha.

\section{[18]}

sakınčtın tägzinür bo sansar .

sakınč1 ${ }^{25}$ üküškädin ${ }^{77}$ yok .

sakınč tözi ämgäk ol .

sakınčsız bolmak täg buyan yok .

By reflection the samsāra turns around,

it is not because one has many reflections.

The essence of reflection is suffering,

there is no (better) punya than being without reflection.

[19]

${ }^{26}$ kök kalık täg etigsiz .

köyül burhan ol tep körzünlär .

${ }^{77}$ This seems to be an $a d$ hoc formation: the dative or the ablative are used for expressing a reason, here in combination of both. Only üküsk $\ddot{a}$ in stanza 17. 
köyülin k1lsar köyülsüz .

köyülin ${ }^{27}$ köyültä tapzunlar ::

They should see that mind is the Buddha

like heaven unaggregated (asamskrta)!

If they make the mind mind-less, they should find the mind in the mind!

[20]

körmäksiz bolmak körmäk ol .

köräyin temäkni tutzunlar .

körmäklig ${ }^{28}[] \mathrm{d}[\quad] \mathrm{p}$.

küsüšsüz kön[ül]]in tuyzunlar ::

The state without seeing is seeing -

they should keep the saying 'I will see'.

They should [give up the desire] of seeing

and perceive the mind of being without desire ${ }^{78}$ !

[21]

alku noomlarnı öz tözi .

amrılmıs (...)

The real essence of all dharmas

$\operatorname{calm}(\ldots)$

\begin{abstract}
Abbreviations
CBETA $=$ CBETA Chinese Electronic Tripitaka Collection

Chin. $=$ Chinese

$\mathrm{D}=$ Dunhuang (in shelf numbers)

DDB = Digital Dictionary of Buddhism (Charles MulLER): http://www.buddhism-dict.net/ddb/ (last access: 2 February 2019)

$\mathrm{DPPN}=$ G. P. Dictionary of Pāli Proper Names. London and Boston, 1974

$\mathrm{ED}=$ Clauson $(1972)$

SAT = Saṃgaṇikīkṛtaṃ Taiśotripițakaṃ. The SAT Daizōkyō Text Database

Skt. $=$ Sanskrit

SWTF $=$ Sanskrit-Wörterbuch der buddhistischen Texte aus den Turfan-Funden und der kanonischen Literatur der Sarvāstivāda-Schule. Ed. Jens-Uwe HARTMANN. Göttingen: Vandenhoeck \& Ruprecht, 1994-2017

T. = Taishō Shinshū Daizōkyō: TAKAKUSU Junjirō 高楠順次郎 and WATANABE Kaigyoku 渡辺海旭 et al. (eds.) 1924-1934. Taishō shinsh̄u daizōkyō 大正新脩大藏経. 100 vols. Tokyo: Taishō Issaikyō Kankōkai

UWN = Röhrborn $(2015,2017)$
\end{abstract}

${ }^{78}$ küsüšsüz 'without desire' is an important Buddhist term, cf. Yakup 2010. 


\section{References}

BRAY, Francesca 1984. Agriculture [Science and Civilisation in China: Volume 6, Biology and Biological Technology; Part II]. Cambridge: Cambridge University Press.

Clauson, Gerard 1972. An Etymological Dictionary of Pre-Thirteenth-Century Turkish. Oxford: Clarendon Press.

DONNER, Kai 1944. Kamassisches Wörterbuch nebst Sprachproben und Hauptzügen der Grammatik. Helsinki: Suomalais-Ugrilainen Seura.

ERDAL, Marcel 1991. Old Turkic Word Formation I-II. Wiesbaden: Harrassowitz.

Golomb, Ludwig 1959. Die Bodenkultur in Ost-Turkestan. Oasenwirtschaft und Nomadentum. [Studia Instituti Anthropos, Vol. 14.] Freiburg: Verlag des Anthropos-Institutes Posieux.

MolnÁR, Ádám und Peter ZiEME 1989. 'Ein weiterer uigurischer Erntesegen.' Altorientalische Forschungen 16: 140-152.

NisHIWAKI, Tsuneki 2014. Chinesische und manjurische Handschriften und seltene Drucke Teil 7. Chinesische Blockdrucke aus der Turfansammlung. [VOHD XII, 7.] Stuttgart: Franz Steiner Verlag.

Norman, Kenneth Roy $2001^{2}$. The Group of Discourses (Sutta-nipāta). Oxford: The Pali Text Society.

Pye, Michael $2003^{2}$. Skilful Means. A Concept in Mahyana Buddhism. London and New York: Routledge.

RADLOFF, Wilhelm 1905. Versuch eines Wörterbuches der Türk-Dialecte. Band 3. Sanktpeterburg.

RÓNA-TAS, András and Árpád BERTA (with the assistance of László KÁROLY) 2011. West Old Turkic. Turkic Loanwords in Hungarian. I-II. Wiesbaden: Harrassowitz.

RÖHRBORN, Klaus 2015, 2017. Uigurisches Wörterbuch. Sprachmaterial der vorislamischen türkischen Texte aus Zentralasien - Neubearbeitung: I. Verben. Stuttgart: Franz Steiner Verlag, 2010. II. Nomina-Pronomina-Partikeln, Bände 1-2. Stuttgart: Franz Steiner Verlag.

SEVORTJAN, Ervand Vladimirovich [Эрванд Владимирович Севортян] 1978. Этимологический словарь тюркских языков. Москва: Наука.

TeKIN, Şinasi 1980. Buddhistische Uigurica aus der Yüan-Zeit. Budapest: Akadémiai Kiadó.

WiLKENS, Jens 2013. 'Review of Y. Kasai, Der alttürkische Kommentar zum Vimalakīrtinirdeśasūtra, Turnhout 2011 (Berliner Turfantexte XXIX).' Orientalistische Literaturzeitung 108: 421-426.

WiLKENS, Jens 2017. 'The Old Uyghur Translation of the Bieyi za ahanjing (1935.52.0012-0015).' In: Yukiyo KasAi et al. (eds.) The Old Uyghur Ägama Fragments Preserved in the Sven Hedin Collection, Stockholm. [Silk Road Studies XV.] Turnhout: Brepols, 197-280.

YAKUP, Abdurushid 2010. Prajñāpāramitā Literature in Old Uyghur. [Berliner Turfantexte XXVIII.] Turnhout: Brepols.

ZIEME, Peter 2005. Magische Texte des uigurischen Buddhismus. [Berliner Turfantexte XXIII.] Turnhout: Brepols.

ZIEME, Peter 2016. 'Sergei F. Oldenburg and the Devatāparipṛcchāsūtra.' In: И. Ф. Попова [сост. и отв. ред.] Сергей Федорович Ольденбург - ученый и организатор науки. Москва: Наука, 366-378.

ZIEME, Peter 2019. 'The Layman İndu and an Old Uigur Poem.' Written Monuments of the Orient (in print).

ZIEME, Peter (in preparation) Minora fragmenta vigvrorvm. [Berliner Turfantexte.] 